\title{
ANALISIS PARAMETER FISIKA-KIMIA UNTUK KEPENTINGAN REHABILITASI EKOSISTEM MANGROVE DI PESISIR PULAU BUNGKUTOKO KOTA KENDARI
}

\author{
Asramid Yasin ${ }^{1}$ \\ ${ }^{1}$ Kesehatan Masyarakat, Fakultas Ilmu Kesehatan Universitas Pembangunan Nasional Veteran Jakarta, Jl. \\ Raya Limo Kelurahan Limo Kecamatan Cinere, Depok Baru, Indonesia 16515, ID Penulis (Sinta) : 5979653, \\ email: asramidyasin@upnvj.ac.id
}

\begin{abstract}
Abstrak
Di beberapa tempat telah dilakukan rehabilitasi terhadap kawasan mangrove yang telah rusak namun pada kenyataannya tidak semua kegiatan rehabilitasi mangrove berhasil dilakukan. Penelitian ini bertujuan mengetahui kondisi parameter lingkungan perairan pantai Bungkutoko Kecamatan Abeli sesuai untuk kegiatan rehabilitasi ekosistem mangrove dan menentukan strategi rehabilitasi yang tepat untuk diterapkan di perairan pantai Bungkutoko Kecamatan Abeli. Penelitian ini dilaksanakan dari bulan Juni-Juli 2009 bertempat di pesisir pulau Bungkutoko Kecamatan Abeli Kabupaten Kendari Sulawesi Tenggara. Data yang diperoleh dalam penelitian ini dianalisis secara deskriptif. Dari hasil pengukuran beberapa parameter fisika-kimia di pesisir pulau Bungkutoko Kecamatan Abeli Kota Kendari yang diperoleh sesuai untuk dilakukan kegiatan rehabilitasi ekosistem mangrove dengan memperhatikan waktu penanaman yang tepat yaitu ketika musim berbuah mangrove dan musim teduh dan menggunakan teknik penanaman secara langsung menggunakan propagul dan penanaman menggunakan anakan (bibit dalam polybag).
\end{abstract}

Kata kunci: mangrove, rehabilitasi dan pesisir

\begin{abstract}
In some places rehabilitation of mangrove areas that have been damaged but in reality not all mangrove rehabilitation activities were successful. This study is aimed to know the condition of coastal environmental parameters in Bungkutoko island, district of Abeli in rehabilitation proposed of mangrove ecosystem and to find a proper rehabilitation strategy for it can be applied in that area. This study was carried on June to July 2009 in the coastal of Bungkutoko island, Abeli district, Kendari Town. Data in this study is analyzed as descriptively. In results of measured some physic-chemical parameters of coastal in Bungkutoko island is suitable for rehabilitation practice of mangrove ecosystem by concern of planting time on the condition of mangrove tree is in having fruits and calm water condition of sea. And also for planting technic is propaguls directly planted to the ground and using seeds on the polybags.
\end{abstract}

Keywords: mangrove, rehabilitation and coastal 


\section{PENDAHULUAN}

Hutan mangrove sebagai salah satu ekosistem yang unik merupakan sumberdaya alam yang sangat potensial. Mangrove mendukung keanekaragaman flora dan fauna dari komunitas teristik akuatik yang berperan penting bagi kelangsungan hidup manusia baik dari segi ekonomis, sosial maupun lingkungan. Di berbagai negara, terutama negara berkembang hutan mangrove merupakan sumberdaya alam yang cukup potensial untuk memberikan sumbangsih yang berarti terhadap pembangunan bangsa dan negara.

Sejalan dengan pesatnya kegiatan pembangunan di berbagai bidang, baik fisik maupun ekonomi, secara langsung maupun tidak langsung telah mempengaruhi pula keadaan hutan mangrove di Indonesia. Hutan mangrove semakin terdesak dan semakin berkurang luasnya sehingga lama-kelamaan dapat menyebabkan terjadinya kemunduran fungsi yang sangat penting baik dari segi pembangunan ekonomi maupun dari segi kelestarian lingkungan.

Penggunaan hasil hutan baik kayu maupun bukan kayu dari hutan mangrove secara tradisional dan bijaksana tidak merusak ekosistem mangrove secara nyata, sebaliknya sangat memberikan manfaat sosial dan ekonomi. Akan tetapi pemanfaatan dan pengalihan fungsi hutan mangrove yang berlebihan dan kurang terencana, justru terbukti telah merusak bahkan menghilangkan ekosistem hutan mangrove. Akibatnya luas areal hutan mangrove semakin mengalami penyusutan. Menurut Darsidi (1987), luas hutan mangrove di Indonesia tahun 1982 sekitar 4,25 juta ha atau kurang lebih $25 \%$ hutan mangrove di dunia. Namun sepuluh tahun kemudian berdasarkan hasil citra Landsat Ness Luasnya berkurang menjadi 3,8 juta ha (Mantodiwirjo, 1994).

Hutan mangrove di Sulawesi Tenggara juga tak luput dari dilema tersebut. Akibat tekanan yang berat dari pertumbuhan penduduk menyebabkan hutan mangrove mengalami degradasi karena kawasan hutan mangrove dikonversi untuk penggunaan lahan lain. Menurut Baharuddin (1994) dari total luas hutan mangrove 112.000 ha yang ditaksir pada awal tahun lima puluhan, maka areal hutan mangrove sekarang ini hanya tersisa 39.000 ha, $65 \%$ diantaranya telah habis ditebang untuk dijadikan tambak, pemukiman atau mengalami degradasi karena ekstrasi untuk pengambilan secara terus menerus tanpa memperhatikan usaha-usaha permudaannya. Ancaman lain berupa limbah pabrik, rumah tangga dan buangan minyak kapal laut. Di samping itu, kurang kesadaran masyarakat untuk memelihara dan adanya persepsi yang salah di masyarakat terhadap hutan mangrove menimbulkan hambatan dalam usaha pelestarian dan rehabilitasi mangrove. 
Mengingat betapa pentingnya peranan hutan mangrove sebagai suatu ekosistem yang utuh, tempat hidup berbagai jenis margasatwa, kiranya perlu dipikirkan cara-cara yang lebih bijaksana dalam mengkonversi hutan mangrove untuk penggunaan lain. Di samping itu juga harus diadakan rehabilitasi atau pemulihan di beberapa tempat yang telah kehilangan hutan mangrovenya.

Dengan demikian, perlu segera dicari pemecahannya secara konsepsional dan operasional antara lain dalam bentuk rehabilitasi atau penanaman kembali kawasan mangrove yang telah mengalami degradasi, agar fungsi ekologis dan ekonomis hutan mangrove dapat dipulihkan. Dalam hal ini, dirasa perlu dilakukan penelitian untuk mengetahui parameter lingkungan pesisir yang mendukung pertumbuhan mangrove, yang dapat digunakan sebagai bahan pertimbangan dalam usaha rehabilitasi atau pemulihan hutan mangrove.

Sehubungan dengan hal tersebut, maka penelitian ini bertujuan untuk mengetahui kondisi parameter lingkungan perairan pantai Bungkutoko Kecamatan Abeli sesuai untuk kegiatan rehabilitasi ekosistem mangrove dan menentukan strategi rehabilitasi yang tepat untuk diterapkan di perairan pantai Bungkutoko Kecamatan Abeli.
Penelitian ini dilaksanakan di Pesisir Pulau Bungkutoko Kecamatan Abeli Kota Kendari, Sulawesi Tenggara. Kegiatan penelitian berlangsung selama 2 bulan, yaitu pada bulan Juni dan Juli 2009. Penentuan lokasi pengamatan merupakan salah satu bagian dalam penelitian yang penting untuk dilakukan. Penentuan stasiun pengamatan pada penelitian ini dilakukan berdasarkan keterkungkungan garis pantai dan kondisi mangrove yang dianggap mewakili seluruh areal lokasi penelitian. Gambaran umum setiap stasiun pengamatan adalah sebagai berikut:

- Stasiun I : Pada daerah pantai yang terlindung (sebelah barat dengan titik koordinat S $03^{\circ} 59^{\prime} 07,8^{\prime \prime}$ dan E $122^{\circ} 36^{\prime}$ $34,2 ")$.

- Stasiun II : Pada daerah pantai yang semi terlindung (sebelah selatan dengan titik koordinat $\mathrm{S} 03^{\circ} 59^{\prime} 30,4^{\prime \prime}$ dan E $122^{\circ} 37^{\prime}$ $17,4 ")$.

- Stasiun III : Pada daerah pantai yang terbuka (sebelah timur dengan titik koordinat $\mathrm{S} 03^{\circ} 58^{\prime} 46,8^{\prime \prime}$ dan E $122^{\circ} 36^{\prime}$ 55,6 ").

\section{METODOLOGI}




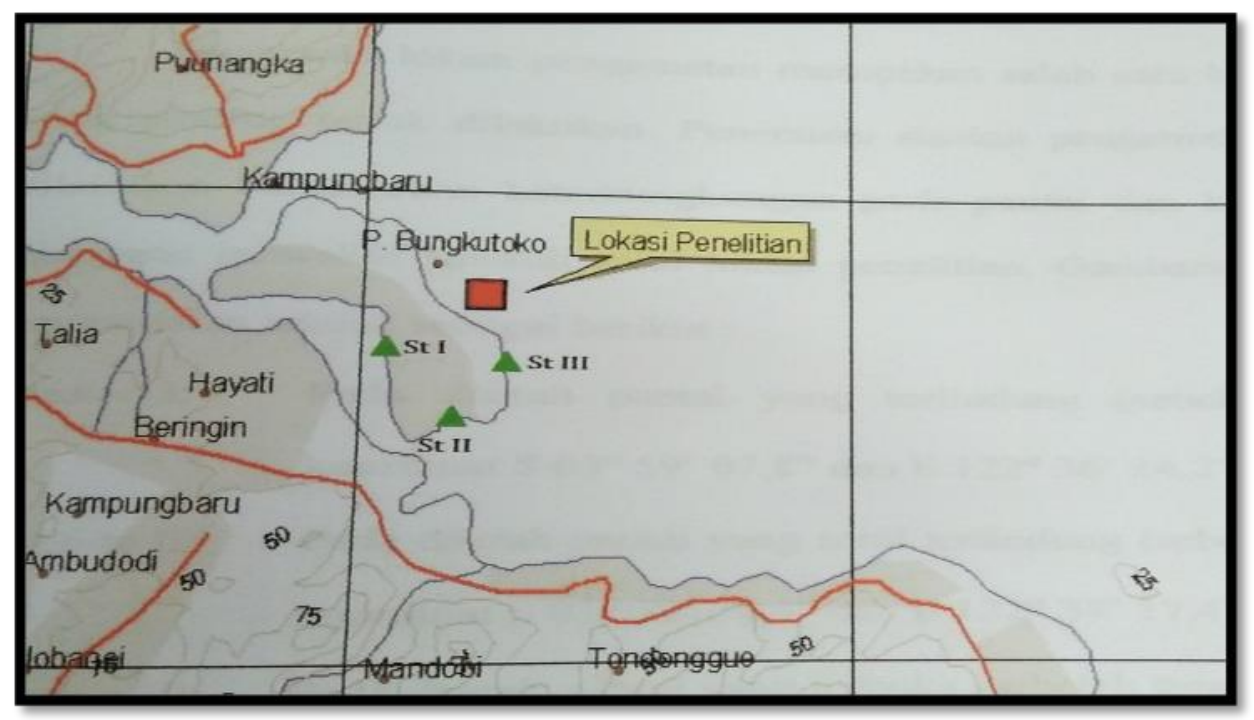

Gambar 1. Lokasi Stasiun Pengamatan

Peralatan yang digunakan selama penelitian

dapat dilihat pada Tabel 1 berikut.

Tabel 1. Alat yang Digunakan Selama Penelitian di Lapangan

\begin{tabular}{|c|c|c|c|c|}
\hline No. & Parameter & Satuan & Alat & Keterangan \\
\hline 1. & Kemiringan Alas & $\%$ & Abney level & In-situ/laboratorium \\
\hline \multirow[t]{3}{*}{2.} & Substrat & & & \\
\hline & a. Ukuran Partikel Substrat & $\%$ & Saringan bertingkat & In-situ/laboratorium \\
\hline & b. Daya Ikat antar Partikel Substrat & $\mu \mathrm{m}$ & Beker glass & In-situ/laboratorium \\
\hline \multirow[t]{4}{*}{3.} & Gelombang & & & \\
\hline & $\begin{array}{ll}\text { a. } & \text { Tinggi Gelombang } \\
\text { b. } & \text { Panjang Gelombang }\end{array}$ & $\mathrm{cm}$ & $\begin{array}{ll}- & \text { Tongkat } \\
& \text { pengukur } \\
- & \text { Meteran } \\
- & \text { Tali }\end{array}$ & In-situ \\
\hline & c. $\quad$ Periode Gelombang & detik & Stopwatch & In-situ \\
\hline & d. Arah Gelombang & - & Kompas geologi & In-situ \\
\hline 4. & $\begin{array}{l}\text { Simpangan Muka Air Laut (Pasang } \\
\text { Surut) }\end{array}$ & $\mathrm{cm}$ & $\begin{array}{ll}- & \text { Tongkat } \\
& \text { pengukur } \\
- & \text { Meteran } \\
- & \text { Jam } \\
- & \text { Senter } \\
\end{array}$ & In-situ \\
\hline \multirow[t]{3}{*}{5.} & Arus & & & \\
\hline & Kecepatan Arus & $\mathrm{m} / \mathrm{s}$ & $\begin{array}{ll}- & \text { Layangan air } \\
- & \text { Meteran } \\
- & \text { Stopwatch } \\
- & \text { Tali } \\
\end{array}$ & In-situ \\
\hline & b. Arah Arus & - & Kompas geologi & In-situ \\
\hline 6. & Sedimen suspensi & $\mathrm{mg} / \mathrm{l}$ & $\begin{array}{ll}- & \text { Timbangan } \\
& \text { analitik } \\
- & \text { Gelas ukur } \\
- & \text { Corong } \\
- & \text { Kertas saring } \\
- & \text { Oven } \\
\end{array}$ & In-situ/laboratorium \\
\hline 7. & Salinitas & $\mathrm{ppt}$ & Hand refraktometer & In-situ \\
\hline 8. & Wawancara & & $\begin{array}{ll}- & \text { Daftar } \\
& \text { pertanyaan } \\
- & \text { Alat tulis } \\
& \text { menulis } \\
\end{array}$ & In-situ \\
\hline
\end{tabular}


Untuk memperoleh gambaran mengenai parameter lingkungan pesisir Pulau Bungkutoko Kecamatan Abeli untuk kepentingan rehabilitasi ekosistem mangrove yang mendukung pertumbuhan atau kehidupan mangrove, maka dikumpulkan data primer dan sekunder. Pengumpulan data primer diperoleh langsung dari hasil pengamatan dan pengukuran di lapangan dan di laboratorium yang meliputi: 1) kemiringan alas pantai diukur pada saat surut terendah. 2) ukuran partikel substrat yaitu sampel substrat diambil pada setiap stasiun yang telah ditentukan, pengambilan sampel ini dilakukan di sekitar pantai maupun saluran pembuangan air dari tambak. 3) daya ikat partikel substrat dilakukan pengamatan langsung di lapangan di perairan pantai Bungkutoko Kecamatan Abeli, kecuali di daerah dekat muara, mata air dan di saluran pembuangan air dari tambak sampelnya diambil dan dianalisis di laboratorium. 4) keterkungkungan garis pantai dilakukan dengan pengamatan langsung di lapangan, keterkungkungan yang dimaksud adalah keterlindungan pantai dari hempasan gelombang. 5) pengukuran tinggi, periode dan arah gelombang yaitu gelombang atau ombak diukur dengan menggunakan tiang berskala dengan mengamati nilai skala puncak dan lembah sampai 50 kali, dari perbedaan pembacaan tinggi (puncak) dan lembah gelombang yang diukur, serangkaian tinggi gelombang dapat dihitung, periode gelombang diukur dengan mencatat banyaknya gelombang yang datang dalam satu selang waktu tertentu.
DOI : doi.org/10.21009/jgg.081.05

6) simpangan muka air laut (pasang surut) yaitu pengukuran pasang surut dilakukan dengan menggunakan papan berskala dan mencatat tinggi muka air tiap jam, papan berskala ditempatkan di lokasi dengan memperhatikan: a) pada daerah pantai terbuka tetapi terlindung dari hempasan gelombang yang besar, b) tidak pernah kering meskipun pada surut terendah, c) kecepatan arus tidak terlalu besar. 7) kecepatan, arah, dan pola arus di perairan diukur dengan menggunakan layangan air dengan tali dengan panjang 10 meter, arus yang diukur adalah arus pada saat surut dan pada saat pasang, kecepatan dihitung dengan membagi panjang tali dengan lamanya waktu penjalarannya hingga tali tegang, sementara arah arus diukur dengan menggunakan kompas geologi. 8) pengukuran sedimen suspensi dilakukan di laboratorium sedangkan salinitas perairan diukur langsung di lapangan.

Pengumpulan data sekunder meliputi: (kecepatan angin, curah hujan dan suhu udara) diperoleh melalui hasil penelitian seperti laporan penelitian instansi atau lembaga yang terkait.

Analisis yang digunakan adalah analisis deskriptif yaitu data yang diperoleh dihitung dan diolah kemudian disajikan dalam bentuk gambar dan tabel untuk memberikan gambaran umum karakteristik lingkungan yang diamati. Selain itu dilakukan analisis perbandingan antara data yang diperoleh dengan batasan atau kriteria kesesuaian parameter lingkungan bagi 
pertumbuhan mangrove yang telah ditetapkan sehingga dapat ditentukan skor dari setiap parameter lingkungan tersebut.

Untuk dapat menentukan tingkat kesesuaian parameter, terlebih dahulu setiap parameter penentu diberi kriteria atau nilai seperti yang disajikan dalam Tabel 2. Supaya setiap parameter lingkungan dapat diberi nilai yang tepat, maka ditetapkan kriteria, batasan dan skor dari setiap kriteria masing-masing komponen atau parameter.

Tabel 2. Kriteria Kesesuaian Pertumbuhan Mangrove Berdasarkan Tipologi Pantai

\begin{tabular}{|c|c|c|c|c|}
\hline \multirow{2}{*}{ Komponen } & \multirow{2}{*}{ Parameter } & \multicolumn{3}{|c|}{ Kriteria } \\
\hline & & Sangat Sesuai & Cukup Sesuai & Kurang Sesuai \\
\hline \multirow{4}{*}{ Morfologi Pantai } & Kemiringan Alas & Landai & Sedang & Terjal \\
\hline & $\begin{array}{l}\text { Daya Ikat antar } \\
\text { Partikel }\end{array}$ & Lepas & Sedang & Kokoh \\
\hline & $\begin{array}{l}\text { Ukuran Partikel } \\
\text { Pembentuk }\end{array}$ & Kecil & Sedang & Besar \\
\hline & $\begin{array}{l}\text { Keterkungkungan } \\
\text { Garis Pantai }\end{array}$ & Terbuka & Semi Tertutup & Tertutup \\
\hline \multirow{3}{*}{$\begin{array}{l}\text { Tinjauan } \\
\text { Dinamika } \\
\text { Perairan Pantai } \\
\text { Berdasarkan } \\
\text { Gaya } \\
\text { Astronomis, } \\
\text { Meteorologis } \\
\text { dan Geologis }\end{array}$} & $\begin{array}{l}\text { Kelancipan Ombak } \\
\text { Datang }\end{array}$ & Lancip & Sedang & Tumpul \\
\hline & $\begin{array}{l}\text { Simpangan Muka Air } \\
\text { Laut }\end{array}$ & Tinggi & Sedang & Rendah \\
\hline & Tipe Pasang Surut & Semi Diurnal & Campuran & Diurnal \\
\hline
\end{tabular}

Setiap parameter kriteria tipologi pantai diberi skor 3 jika berada dalam rentangan sangat sesuai, skor 2 jika berada dalam rentangan cukup sesuai dan skor 1 jika berada dalam rentangan yang kurang sesuai sedangkan untuk nilai total skor dari setiap parameter jika diperoleh pada kisaran 7-11 berada dalam kriteria daerah yang kurang sesuai untuk mangrove, kisaran 12-18 berada dalam kriteria daerah yang sesuai untuk mangrove dan untuk kisaran 19-20 berada dalam kriteria daerah yang sangat sesuai untuk mangrove dan untuk jelasnya dapat dilihat pada Tabel 3 dan Tabel 4 sebagai berikut.
Tabel 3. Ketentuan Penilaian Parameter Tipologi Pantai

\begin{tabular}{c|c}
\hline Kriteria & Skor \\
\hline Sangat sesuai & 3 \\
Cukup sesuai & 2 \\
Kurang sesuai & 1 \\
\hline
\end{tabular}

Sumber: Sobur (1997) dalam Amal (2000)

Tabel 4. Ketentuan Penilaian Parameter Tipologi Pantai

\begin{tabular}{l|c}
\hline \multicolumn{1}{|c|}{ Kriteria } & $\begin{array}{c}\text { Kisaran Nilai } \\
\text { Total Skor }\end{array}$ \\
\hline $\begin{array}{l}\text { Daerah yang kurang sesuai untuk } \\
\text { mangrove }\end{array}$ & $7-11$ \\
$\begin{array}{l}\text { Daerah yang sesuai untuk mangrove } \\
\text { Daerah yang sangat sesuai untuk } \\
\text { mangrove }\end{array}$ & $12-18$ \\
\hline
\end{tabular}

Sumber: Sobur (1997) dalam Amal (2000)

Selanjutnya dalam menentukan jenis mangrove apa yang akan ditanam, apabila parameter yang diteliti masih sesuai untuk dilakukan rehabilitasi maka informasi atau hasil nilai dari parameter-parameter tersebut dapat dibandingkan dengan literatur acuan 
yang terkait dengan penentuan jenis mangrove apa yang cocok untuk ditanami.

Sedangkan penentuan waktu yang tepat untuk melakukan penanaman adalah dengan mempertimbangkan musim berbuah dan kondisi oseanografinya seperti musim angin kencang, musim hujan, ombak besar, arus kuat dan jadwal pasang surut dimana informasi tersebut dapat diperoleh dari hasil penelitian dan wawancara langsung dengan masyarakat setempat sehingga dapat diketahui waktu yang baik untuk memulai penanaman.

Untuk teknik rehabilitasi yang akan diterapkan, secara umum ada dua yaitu penanaman dengan menggunakan propagul dan penanaman dengan menggunakan anakan (bibit dalam polybag) (Kusmana dkk., 2003).

\section{HASIL DAN PEMBAHASAN}

Di Kabupaten Kendari Kecamatan Abeli Kelurahan Bungkutoko pada umumnya curah hujan yang terjadi tiap tahun sangat bervariasi tergantung arus angin yang bertiup di atas wilayahnya. Pada bulan Mei sampai dengan bulan Agustus, angin bertiup dari arah timur berasal dari benua Australia yang kurang uap air. Hal ini mengakibatkan terjadinya musim kemarau (kurangnya curah hujan) tepatnya pada bulan Agustus sampai dengan Oktober. Kemudian pada bulan November sampai dengan bulan Maret terjadi musim hujan (curah hujan tinggi), angin bertiup banyak mengandung uap air yang berasal dari benua
Asia dan Samudera Pasifik. Menurut data dari Lanud Wolter Monginsidi Kendari tahun 20032007 terjadi 132-205 hari hujan dengan curah hujan 1.555,6 - $3.467 \mathrm{~mm}$.

Secara keseluruhan wilayah Kota Kendari bersuhu tropis. Menurut data dari Lanud Wolter Monginsidi Kendari tahun 2003-2007 suhu udara maksimum 31,58-33,75 ${ }^{\circ} \mathrm{C}$ dan minimum $20,00-23,25^{\circ} \mathrm{C}$ sedangkan kecepatan angin $3,75-12,75 \mathrm{~m} / \mathrm{s}$.

Jenis vegetasi mangrove yang umum ditemukan di sepanjang pesisir pulau Bungkutoko adalah jenis mangrove dari famili Rhizophoraceae (Rhizophora spp.) dan Sonneratiaceae (Sonneratia spp.). Vegetasi mangrove ini tumbuh dan hidup di pinggir pantai secara berkelompok-kelompok dan di sebelah selatan tidak membentuk suatu kawasan hutan yang lebat kecuali di sebelah barat yang kawasan hutan mangrovenya agak lebih lebat sedangkan untuk di sebelah timur kawasan hutan mangrovenya tinggal sedikit. Di Bungkutoko bagian barat yang merupakan stasiun I banyak dijumpai vegetasi mangrove di pinggir muara teluk sedangkan di bagian selatan yang merupakan stasiun II kurang dijumpai vegetasi mangrove karena adanya pemukiman yang ditinggali oleh masyarakat setempat dan untuk di bagian timur yang merupakan stasiun III juga kurang dijumpai vegetasi mangrove akibat adanya pemukiman dan saat ini ditambah dengan adanya pembangunan kontainer sehingga luas kawasan hutan mangrove semakin berkurang. 
Gambaran umum keadaan pantai dan parameter oseanografis diketahui berdasarkan hasil wawancara dengan beberapa penduduk (nelayan) yang tinggal di pesisir pulau Bungkutoko Kecamatan Abeli. Wawancara tersebut dilakukan khususnya tentang keadaan pantai maupun parameter oseanografis yang diteliti. Hasil-hasil wawancara disusun pada Tabel 5 berikut.

Tabel 5. Hasil Wawancara dengan Penduduk Setempat tentang Keadaan Pantai dan Parameter Oseanografis

\begin{tabular}{|c|c|c|}
\hline No. & Bahan Diskusi & Jawaban (\% Responden) \\
\hline 1. & $\begin{array}{l}\text { Ketinggian ombak } \\
\text { maksimum }\end{array}$ & $\begin{array}{l}1-3 \mathrm{~m} \text { (biasanya mencapai } 1,5 \mathrm{~m}) \\
(100 \%)\end{array}$ \\
\hline 2. & $\begin{array}{l}\text { Waktu terjadinya } \\
\text { ombak tertinggi }\end{array}$ & $\begin{array}{l}\text { Musim Timur (Juni-September) } \\
\text { (biasanya terjadi di bulan } \\
\text { September) }(100 \%)\end{array}$ \\
\hline 3. & Tipe pasang surut & $\begin{array}{l}\text { Dua kali pasang dua kali surut (100 } \\
\%)\end{array}$ \\
\hline 4. & $\begin{array}{l}\text { Siklus badai (angin } \\
\text { kencang) }\end{array}$ & $\begin{array}{l}\text { Setahun } 3 \text { kali pada waktu angin } \\
\text { timur, angin barat, angin selatan dan } \\
\text { yang paling kencang terjadi pada } \\
\text { waktu angin timur }(80 \%) \\
\text { Setahun } 1 \text { kali pada waktu angin } \\
\text { timur }(20 \%)\end{array}$ \\
\hline 5. & Air meluap & $\begin{array}{l}\text { Pengaruh dari muara teluk Kendari } \\
\text { dan hujan terus menerus pada saat } \\
\text { musim angin barat setiap satu tahun } \\
\text { sekali. } \\
\text { Terjadi pada bulan April }(70 \%) \\
\text { Terjadi pada bulan Februari-April } \\
(30 \%)\end{array}$ \\
\hline 6. & $\begin{array}{l}\text { Rentang pasang } \\
\text { tertinggi dan surut } \\
\text { terendah }\end{array}$ & $\begin{array}{l}>2 \mathrm{~m}(10 \%) \\
1-2 \mathrm{~m}(90 \%)\end{array}$ \\
\hline 7. & $\begin{array}{l}\text { Kadar garam/ salinitas } \\
\text { pada saat musim } \\
\text { hujan }\end{array}$ & $\begin{array}{l}>20 \%(60 \%) \\
20-30 \% \text { \% }(40 \%)\end{array}$ \\
\hline
\end{tabular}

Parameter fisika-kimia perairan pantai yang diukur pada penelitian ini meliputi Kemiringan Alas (Topografi Pantai), Substrat (Ukuran Partikel dan Daya Ikat Partikel), Gelombang, Simpangan Muka Air Laut (Pasang Surut), Arus, Sedimen Suspensi dan Salinitas yang dapat diuraikan sebagai berikut.

Pada pengukuran langsung di lapangan dengan menggunakan abney level dan meteran roll yang diukur pada setiap lokasi atau stasiun penelitian pada jarak 50 meter dari garis pantai hingga batas surut terjauh dari masing-masing stasiun diperoleh kemiringan alas untuk stasiun I yaitu $0,1 \%$ sedangkan di stasiun II yaitu $3 \%$ dan di stasiun III yaitu 3,2 \%. Adapun hasil pengukuran kemiringan alas pada masingmasing stasiun dapat dilihat pada Tabel 6 berikut.

Tabel 6. Hasil Pengukuran Kemiringan Alas pada Masing-Masing Stasiun

\begin{tabular}{|c|c|}
\hline Stasiun & Jumlah Jarak \\
\hline I & 150 meter $=0,1 \%$ \\
\hline II & 400 meter $=3 \%$ \\
\hline III & 450 meter $=3,2 \%$ \\
\hline
\end{tabular}

Berdasarkan nilai yang diperoleh di atas, menunjukkan bahwa topografi pantai di stasiun I termasuk datar sedangkan di stasiun II dan III termasuk landai. Berikut klasifikasi kemiringan tanah atau kelerengan tanah tunggal dapat dilihat pada Tabel 7 berikut:

Tabel 7. Klasifikasi Kemiringan Tanah atau Kelerengan Tanah Tunggal

\begin{tabular}{|l|l|c|}
\hline No. & \multicolumn{1}{|c|}{ Klasifikasi } & Interval Nilai \\
\hline 1. & Datar & $<3 \%$ \\
\hline 2. & Landai & $3-8 \%$ \\
\hline 3. & Agak Miring & $8-15 \%$ \\
\hline 4. & Miring & $15-30 \%$ \\
\hline 5. & Agak Curam & $30-45 \%$ \\
\hline 6. & Curam & $45-65 \%$ \\
\hline 7. & Terjal & $>65 \%$ \\
\hline
\end{tabular}
Sumber: Hardjowigeno, 1992

Ukuran partikel substrat suatu pantai dipengaruhi oleh beberapa faktor antara lain adalah besarnya gelombang dan arus yang masuk dan runoff yang mensuplai sedimen dari darat. Gelombang dan arus yang relatif tenang menyebabkan ukuran partikel halus yang diendapkan lebih dahulu kemudian disusul sedimen ukuran sedang sampai kasar. Indikasi 
ini dapat dilihat pada setiap stasiun berikut. pengamatan yang disajikan pada Tabel 8

Tabel 8. Persentase Rata-Rata Pasir Kasar, Pasir Halus, Debu dan Liat pada Setiap Stasiun Pengamatan

\begin{tabular}{|c|c|c|c|c|c|}
\hline \multirow{2}{*}{ Stasiun } & Pasir Kasar & Pasir Halus & Lanau/Debu & Liat & \multirow{2}{*}{ Kriteria } \\
\cline { 2 - 5 } & $0,5-1 \mathrm{~mm}$ & $0,125-0,25 \mathrm{~mm}$ & $0,0039-0,0625 \mathrm{~mm}$ & $<0,0039 \mathrm{~mm}$ & \\
\hline I & $5,797 \%$ & $31,981 \%$ & $53,237 \%$ & $8,213 \%$ & Lempung berdebu \\
\hline II & $15,667 \%$ & $26,982 \%$ & $47,679 \%$ & $8,8 \%$ & Lempung berpasir \\
\hline III & $4,532 \%$ & $48,374 \%$ & $36,650 \%$ & $10,049 \%$ & Lempung berpasir \\
\hline
\end{tabular}

Bahasan tentang konsistensi atau

kerekatan butiran tanah, berkaitan erat dengan

Di Tabel 8 terlihat bahwa persentase ukuran partikel masing-masing stasiun berbeda. Di stasiun I dan II persentase debu yang lebih dominan yaitu 53,237 \% dan 47,679 $\%$, hal ini disebabkan karena keberadaan aliran air dari muara Teluk Kendari yang mensuplai sedimen dari darat yang selanjutnya didukung oleh gelombang dan arus yang relatif tenang, mengakibatkan terjadinya pengendapan partikel yang lebih halus seperti debu.

Lain halnya di stasiun III persentase pasir halus yang lebih dominan yaitu 48,374 \%, hal ini disebabkan karena pengaruh aliran dari muara teluk sangat kecil dan gelombang serta arus yang relatif lebih cepat dibandingkan dengan stasiun I dan II sehingga didapatkan ukuran partikel yang mengendap pun adalah agak kasar.

Konsistensi tanah adalah sifat yang melukiskan kekuatan rekat butiran tanah satu dengan lain. Konsistensi tanah menunjukkan kekuatan daya kohesi butir-butir tanah atau daya adhesi butir tanah dengan benda lain. Tiap bahan substrat atau tanah memiliki konsistensi (Hardjowigeno, 1992). tingkat kestabilan substrat atau kematangan substrat mangrove. Menurut Kusmana $d k k$., (2003) mengatakan bahwa tanah mangrove biasa dikategorikan berdasarkan kematangannya. Tanah yang belum matang biasanya disebut lunak atau lembek sehingga orang yang berjalan di atasnya terperosok jauh ke bawah sedangkan tanah yang sudah matang biasanya disebut stabil atau keras sehingga orang yang berjalan di atasnya tidak mengalami kejadian terperosok ke bawah.

Berdasarkan hasil analisis tingkat kematangan substrat pada masing-masing stasiun. Menunjukan bahwa di stasiun I dan II bersifat lunak atau lembek yang mengindikasikan bahwa substrat tersebut belum begitu matang atau stabil hal ini disebabkan karena kedua stasiun tersebut berada pada daerah pantai yang terlindung dari gempuran ombak dan kecepatan arus yang lemah sehingga sedimen yang terakumulasi atau mengendap pun ukuran partikelnya halus. Sedangkan di stasiun III bersifat lepas yang mengindikasikan bahwa butir-butiran tanah tidak melekat antara satu sama lain dengan kata lain tidak memiliki daya ikat hal ini 
disebabkan karena stasiun tersebut berada pada daerah pantai terbuka yang langsung mendapat tekanan dari ombak dan arus sehingga sedimen yang didapat pun ukuran partikelnya agak kasar.

Gelombang dipengaruhi oleh dorongan angin di atas permukaan laut. Semakin kencang angin bertiup, makin lama angin bertiup dan semakin luas daerah yang dilewati oleh angin maka gelombang yang ditimbulkan makin besar. Hasil analisis pengukuran gelombang pada masing-masing stasiun di stasiun II dan III didapatkan tinggi, panjang dan periode gelombang yang signifikan, hal ini dapat dilihat pada Gambar 2 berikut.

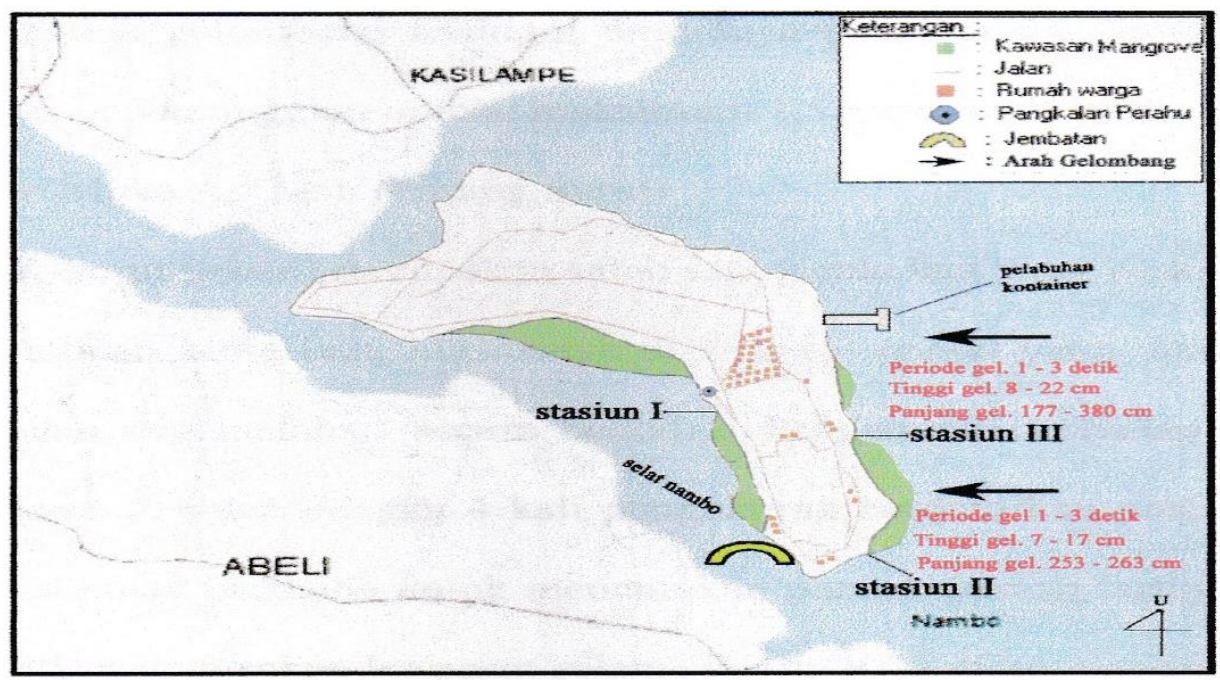

Gambar 2. Kisaran Gelombang dan Arah Gelombang di Setiap Stasiun Pengamatan

Dari Gambar 3 tersebut menunjukkan bahwa tinggi, panjang dan periode gelombang signifikan yang terukur secara berturut-turut berkisar antara 7-17 cm, 253-263 $\mathrm{cm}$ dan 1-3 detik di stasiun II, 8-22 cm, 177-380 cm dan 1-3 detik di stasiun III. Arah gelombang miring terhadap garis pantai yang berasal dari timur, hal ini terjadi ketika gelombang memasuki perairan pantai, dasar gelombang telah menyentuh dasar laut maka arah gelombang akan dibelokkan ke arah pantai dan kecepatan gelombang teredam oleh dasar pantai. Kisaran tinggi, panjang dan periode gelombang tersebut relatif kecil disebabkan karena angin sebagai pembangkit gelombang bertiup sepoi-sepoi dan lemah dan merupakan pantai yang landai. Besar dan arah gelombang yang menuju pantai berkaitan langsung dengan besar dan kecepatan angin sehingga gelombang dapat diprediksi dari hasil wawancara masyarakat setempat yang sehari-hari beraktivitas di perairan pantai Bungkutoko. Dari hasil wawancara tersebut, diperoleh gelombang tertinggi umumnya pada musim timur (bulan Juni-September) dengan ketinggian ombak maksimum 1,5 meter pada bulan September.

Pasang-surut (pasut) merupakan salah satu gejala laut yang besar pengaruhnya terhadap kehidupan biota laut, khususnya di wilayah 
pantai yang dipengaruhi oleh gaya tarik bulan dan matahari secara berkala. Pengamatan terhadap pasang surut dilakukan selama 2 bulan dengan 4 kali pengukuran berdasarkan posisi bulan yaitu bulan baru dan bulan purnama untuk menemukan puncak pasang tertinggi, selain itu juga dikumpulkan data sekunder pasut selama tahun 2009 untuk menemukan rentang pasut dan frekuensi penggenangan selama satu tahun.

Berdasarkan hasil pengukuran pasut di lapangan diperoleh seirama dengan data pasut pangkalan angkatan laut dimana didapatkan

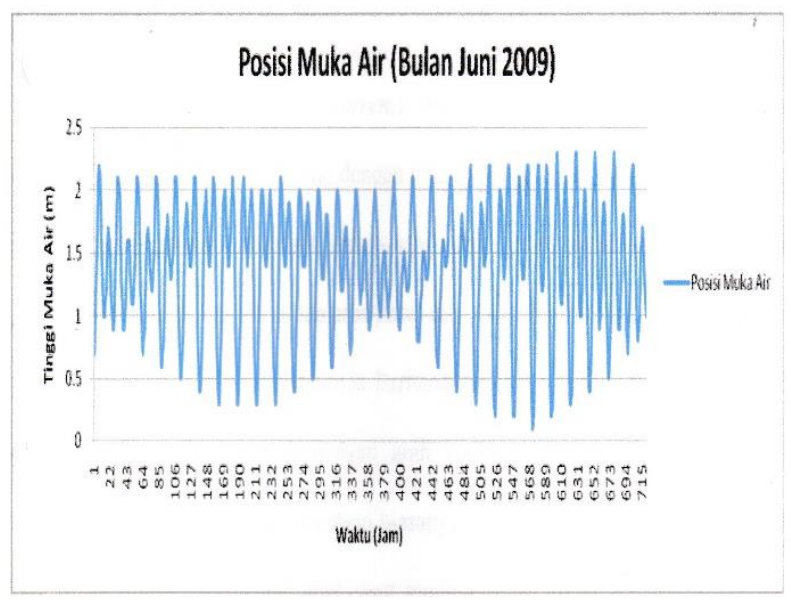

Sumber: Pangkalan TNI AL Kendari, 2009

\section{DOI : doi.org/10.21009/jgg.081.05}

tipe pasut surut termasuk tipe campuran condong ke harian ganda dengan rentang pasang surut tertinggi adalah $210 \mathrm{~cm}$ selama pasang purnama (terjadi pada bulan Juni), $170 \mathrm{~cm}$ selama pasang perbani (terjadi pada bulan September) dan tinggi muka air tertinggi yang dicapai pada saat air pasang dalam pengaruh matahari dan bulan adalah $110 \mathrm{~cm}$ dari MSL (dapat dilihat pada Gambar 3 dan 4). Sedangkan untuk frekuensi penggenangan diperoleh 558 kali per tahun.

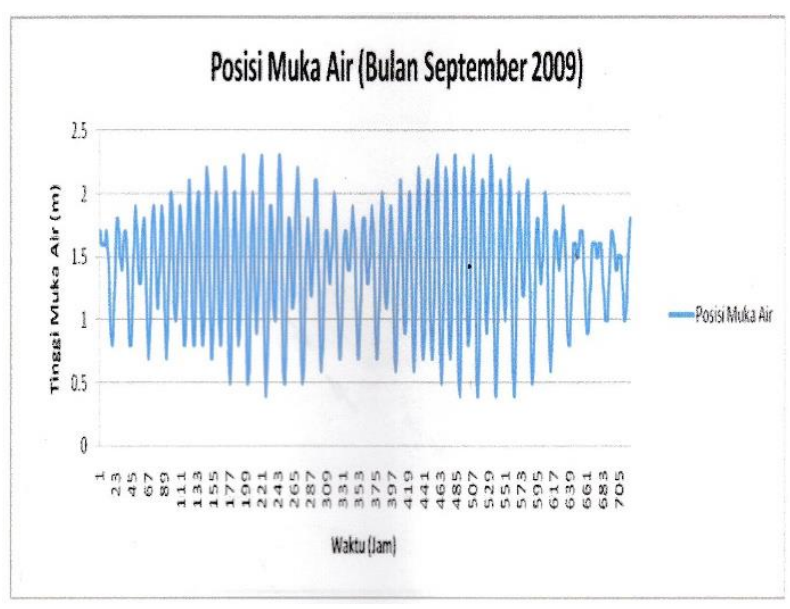

Gambar 3 \& 4. Kurva Pasang Surut di Pulau Bungkutoko

Arus pasang surut (tidal current) merupakan gerak horizontal badan air menuju dan menjauhi pantai seiring dengan naik turunnya muka laut yang disebabkan oleh gaya-gaya pembangkit pasut, arus pasang surut (pasut) terjadi karena mengikuti pergerakkan pola pasang surut dan arus pasut mengikuti bentuk dasar laut di perairan pantai (Pariwono, 1989). Selanjutnya Pariwono

(1989) menambahkan bahwa arus pasut memilliki sifat bergerak dengan arah yang saling bertolak belakang (bidirectional), arah arus saat air meninggi biasanya bertolak belakang dengan arah arus saat air merendah. Kecepatan arus pasut minimum atau efektif nol terjadi saat air tinggi atau air rendah (slack waters). Kecepatan dan arah arus yang terukur pada 
masing-masing stasiun disajikan pada Gambar 5 berikut.

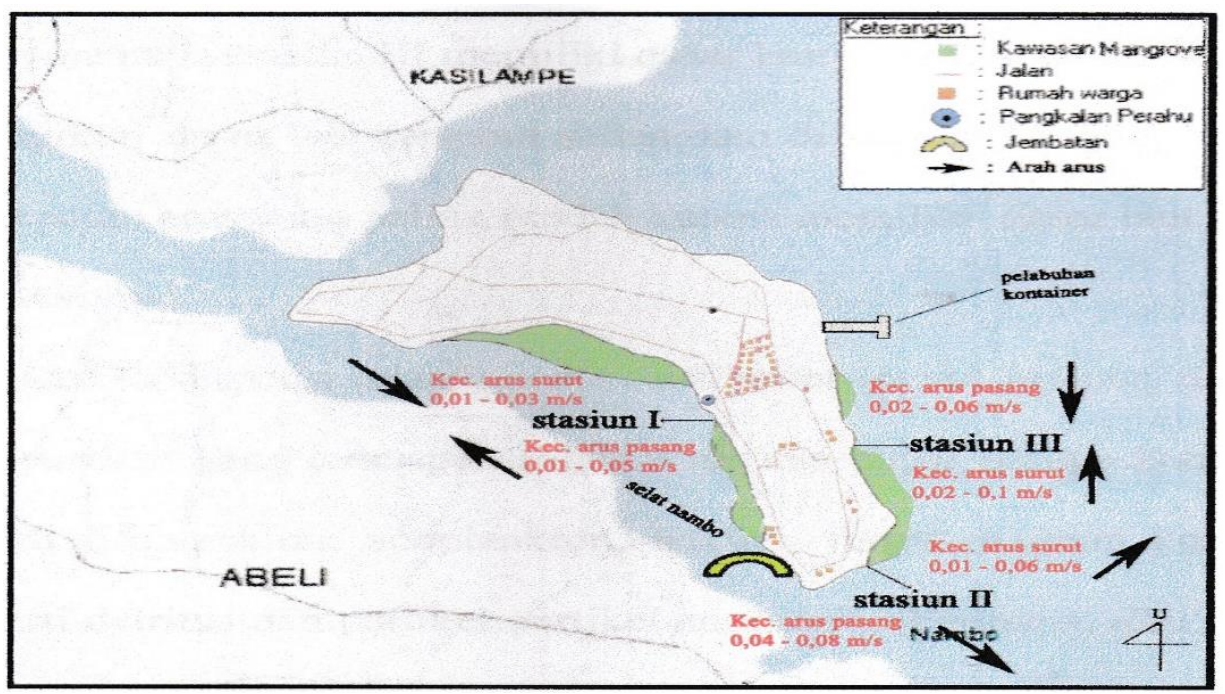

Gambar 5. Kisaran Kecepatan Arus dan Arah Arus di Setiap Stasiun Pengamatan

Hasil pengamatan menunjukkan bahwa di stasiun I kisaran kecepatan arus diperoleh 0,01 sampai $0,03 \mathrm{~m} / \mathrm{s}$ dengan arah arus ke tenggara pada saat sedang surut dan saat sedang pasang kecepatan arus 0,01 sampai 0,05 m/s dengan arah arus ke barat laut. Sedangkan di stasiun II kisaran kecepatan arus pada saat sedang pasang 0,04-0,08 $\mathrm{m} / \mathrm{s}$ dengan arah arus ke tenggara dan saat sedang surut $0,01-0,06 \mathrm{~m} / \mathrm{s}$ dengan arah arus ke timur laut. Selain itu juga, di stasiun III diperoleh kisaran kecepatan arus pada saat sedang surut $0,02-0,1 \mathrm{~m} / \mathrm{s}$ dengan arah arus ke utara dan pada saat pasang kecepatan arus 0,02-0,06 m/s dengan arah arus ke selatan.

Dari kisaran kecepatan arus yang diperoleh dari setiap stasiun, diketahui bahwa stasiun III memiliki kecepatan arus yang paling tinggi dibandingkan dengan stasiun lainnya yang terjadi pada saat sedang surut, hal ini dipengaruhi oleh bentuk dasar laut dimana pada stasiun III memiliki dasar laut yang landau sehingga arus pasut bergerak mengikuti dasar laut tersebut sedangkan di stasiun I terjadi hal sebaliknya memiliki kecepatan arus yang paling rendah karena memiliki dasar laut yang datar.

Zat padat tersuspensi adalah semua zat padat (pasir, lumpur dan tanah liat) atau partikel-partikel yang tersuspensi dalam air dan dapat berupa komponen hidup (biotik) seperti fitoplankton, zooplankton, bakteri, fungi ataupun komponen mati (abiotik) seperti detritus dan partikel-partikel anorganik (Permana, dkk., 1994 dalam Taringan dan Edward, 2003).

Pulau Bungkutoko merupakan sebuah pulau yang terletak di mulut Teluk Kendari dimana aliran air muara teluk yang setiap saat membawa sejumlah material sedimen yang akan diendapkan di pantai. Material-material tersebut akan diangkut dan disebarkan oleh 
bantuan arus rip, longshore current dan arus

balik. Hasil pengukuran sedimen suspensi

dapat dilihat pada Gambar 6 berikut.

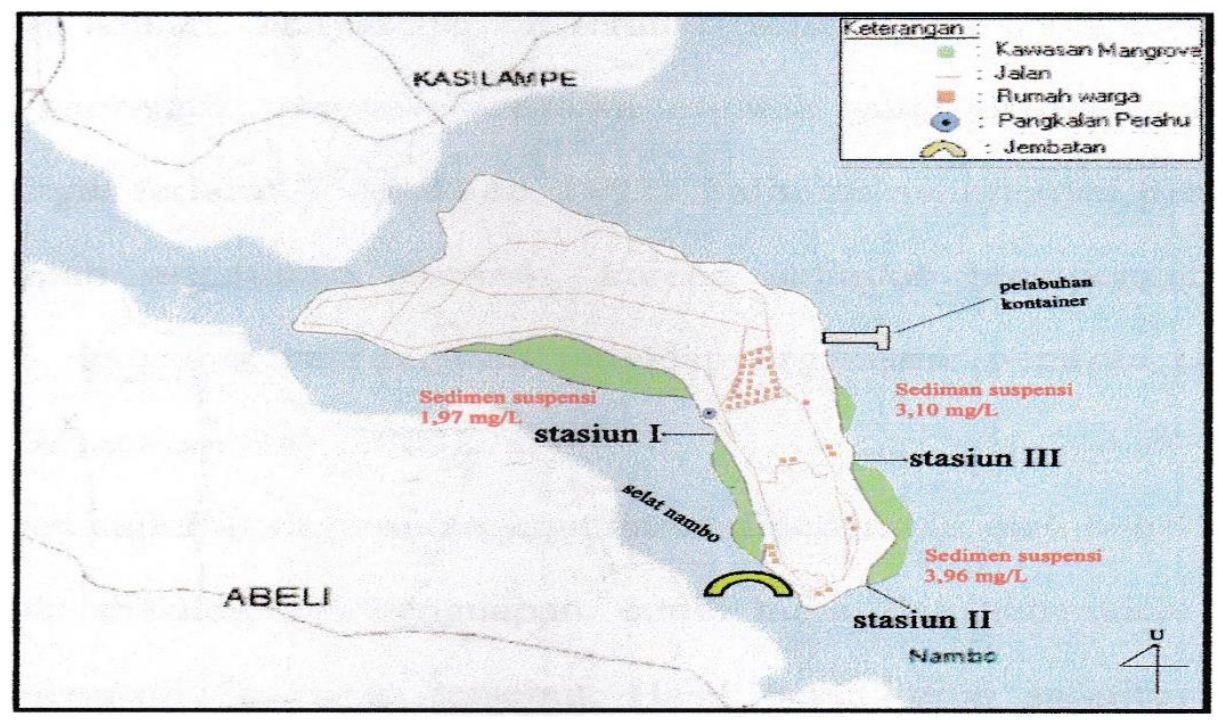

Gambar 6. Kisaran Sedimen Suspensi di Setiap Stasiun Pengamatan

Analisis sedimen suspensi yang dilakukan memperlihatkan bahwa kadar suspensi secara keseluruhan yang didapatkan dari setiap stasiun mulai dari 1,97 mg/l hingga 3,96 mg/l. Diantara setiap stasiun kadar sedimen suspensi yang tinggi ditemukan pada lokasi stasiun II, hal ini disebabkan karena pada stasiun II merupakan areal yang dekat dengan pemukiman warga sehingga pasokan sedimen berasal dari daerah pemukiman tersebut yang mengalir ke laut dan ditambah dengan aliran air yang berasal dari muara Teluk Kendari.

Sebaran zat padat tersuspensi di laut antara lain dipengaruhi oleh masukan yang berasal dari darat melalui aliran sungai, ataupun dari udara dan perpindahan karena resuspensi endapan akibat pengikisan (Permana, dkk., 1994 dalam Taringan dan Edward, 2003).

Salinitas adalah banyaknya zat terlarut, seperti zat padat terlarut meliputi garam-garam anorganik, senyawa-senyawa organik yang berasal dari organisme hidup, dan gas-gas terlarut (Nybakken, 1992). Salinitas mempunyai peranan penting dalam kehidupan organisme perairan, karena salinitas mempengaruhi tekanan osmotik dan langsung berpengaruh terhadap organisme perairan (Afrianto dan Liviawaty, 1991 dalam Ona, 2004).

Fluktuasi salinitas di perairan juga dapat dipengaruhi oleh beberapa hal yaitu antara lain pola sirkulasi air, penguapan, curah hujan dan banyaknya pasokan air tawar yang memasuki perairan tersebut. Hasil pengukuran salinitas pada setiap stasiun pengamatan selama penelitian adalah berkisar antara 25-37 ppt. sebaran nilai tersebut dapat dilihat pada Gambar 7 berikut. 


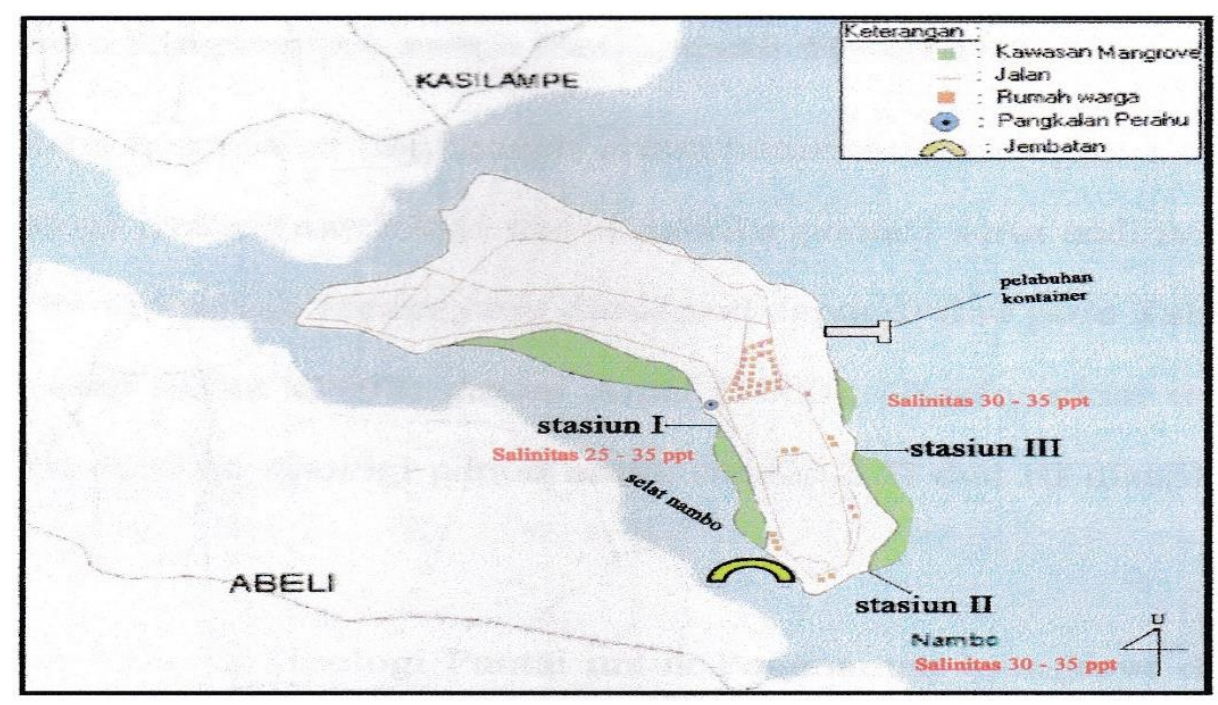

Gambar 7. Kisaran Salinitas di Setiap Stasiun Pengamatan

Dari Gambar 7 di atas terlihat jelas bahwa salinitas pada stasiun I memiliki kisaran yang paling rendah yaitu 25 sampai 35 ppt dibandingkan pada stasiun II dan III yang memiliki kisaran 30 sampai 35 ppt hal ini disebabkan karena stasiun I mendapat pengaruh air tawar dari muara teluk dan air hujan pada saat pengukuran sedangkan pada stasiun II dan III dominan air laut yang berasal dari laut lepas kecuali hanya pada saat hujan. Namun secara umum kisaran salinitas pada ketiga stasiun tersebut masih dalam tahap yang stabil atau masih mendukung pertumbuhan mangrove. Hal ini didukung oleh Suriamihardja dan Amin (1988) dalam Amal (2000) bahwa salinitas 25-40 ppt sangat sesuai bagi persyaratan pertumbuhan mangrove dan selanjutnya Dedi (2009) mengemukakan bahwa salinitas optimum yang dibutuhkan mangrove untuk tumbuh berkisar antara 10-30 ppt.

Analisis kesesuaian lingkungan untuk penanaman mangrove didasarkan pada kondisi tipologi pantai (morfologi dan dinamika pantai) serta sedimen suspensi dan salinitas. Kriteria tipologi pantai yang dimaksud dapat dilihat pada Tabel 2 yang telah dirumuskan oleh Sobur (1997) dalam Amal (2000). Berdasarkan tinjauan tipologi pantai tersebut kriteria tipologi pantai untuk stasiun I, II dan III disajikan pada Tabel 9 berikut.

Tabel 9. Skor Kriteria Tipologi Pantai untuk Penanaman Mangrove di Pesisir Pulau Bungkutoko

\begin{tabular}{|c|c|c|c|}
\hline \multirow{2}{*}{ Parameter } & \multicolumn{3}{|c|}{ Kriteria (Skor) } \\
\hline & Stasiun I & Stasiun II & Stasiun III \\
\hline Kemiringan Alas & $\begin{array}{l}\text { Sedang } \\
\text { (2) }\end{array}$ & $\begin{array}{l}\text { Landai } \\
\text { (3) }\end{array}$ & $\begin{array}{l}\text { Landai } \\
\text { (3) }\end{array}$ \\
\hline Daya Ikat antar Partikel Substrat & $\begin{array}{l}\text { Sedang } \\
(2)\end{array}$ & $\begin{array}{l}\text { Sedang } \\
\text { (2) }\end{array}$ & $\begin{array}{l}\text { Lepas } \\
\text { (3) }\end{array}$ \\
\hline Ukuran Partikel Substrat & $\begin{array}{c}\text { Kecil } \\
(3)\end{array}$ & $\begin{array}{c}\text { Kecil } \\
(3)\end{array}$ & $\begin{array}{c}\text { Kecil } \\
(3)\end{array}$ \\
\hline
\end{tabular}




\begin{tabular}{|c|c|c|c|}
\hline Keterlindungan Garis pantai & $\begin{array}{c}\text { Terlindung } \\
\text { (3) }\end{array}$ & $\begin{array}{l}\text { Semi Terlindung } \\
\text { (2) }\end{array}$ & $\begin{array}{l}\text { Semi Terlindung } \\
\text { (2) }\end{array}$ \\
\hline Kelancipan Ombak Datang & $\begin{array}{c}\text { Bebas Ombak } \\
\text { (3) }\end{array}$ & $\begin{array}{l}\text { Lancip } \\
\text { (3) }\end{array}$ & $\begin{array}{l}\text { Lancip } \\
\text { (3) }\end{array}$ \\
\hline Simpangan Muka Air Laut & $\begin{array}{l}\text { Sedang } \\
(2)\end{array}$ & $\begin{array}{l}\text { Sedang } \\
(2)\end{array}$ & $\begin{array}{l}\text { Sedang } \\
(2)\end{array}$ \\
\hline Tipe Pasang Surut & $\begin{array}{c}\text { Campuran Condong } \\
\text { Harian Ganda } \\
\text { (2) }\end{array}$ & $\begin{array}{c}\text { Campuran Condong } \\
\text { Harian Ganda } \\
\text { (2) }\end{array}$ & $\begin{array}{c}\text { Campuran } \\
\text { Condong Harian } \\
\text { Ganda } \\
(2)\end{array}$ \\
\hline Total Skor & 17 & 17 & 18 \\
\hline
\end{tabular}

Sumber: Dimodifikasi dari Sobur (1997) dalam Amal (2000)

Menurut klasifikasi Sobur (1997) dalam Amal (2000), kisaran nilai skor 7-11 merupakan daerah yang kurang sesuai untuk mangrove, 12-18 sesuai untuk mangrove dan 19-20 sangat sesuai untuk mangrove. Berdasarkan hasil evaluasi pada Tabel 9 dengan kisaran nilai 17-18, maka stasiun I, II dan III masih sesuai untuk penanaman kembali mangrove berdasarkan tinjauan tipologi pantai. Selain itu tinggi gelombang yang relatif kecil berkisar 7-22 cm (kecuali musim timur) dan arus pasang surut lemah berkisar 0,01-0,1 m/s juga ikut mendukung bagi pertumbuhan mangrove, hal ini didukung oleh Suriamihardja dan Amin (1988) dalam Amal (2000) bahwa kecepatan arus $<0,5 \mathrm{~m} / \mathrm{s}$ dan tinggi gelombang $<1 \mathrm{~m}$ sangat sesuai bagi persyaratan pertumbuhan mangrove.

Selanjutnya untuk hasil pengamatan sedimen suspensi dan salinitas di lokasi penelitian (stasiun I, II dan III) diperoleh sedimen suspensi 1,97-3,96 mg/l dan salinitas 25-35 ppt. Nilai-nilai tersebut menunjukkan kondisi yang cukup baik bagi kehidupan mangrove hal ini ditunjukkan pula oleh tumbuhnya pohon mangrove dengan baik di lokasi penelitian. Menurut Suriamihrdja dan Amin (1988) dalam Amal (2000) bahwa salinitas 25-40 ppt sangat sesuai bagi persyaratan pertumbuhan mangrove.

Jenis vegetasi mangrove yang umum ditemukan di pulau Bungkutoko adalah famili Rhizophoraceace (Rhizophora spp.) dan Sonneraticeae (Sonneratia spp.) yang hidup berada di pinggir garis pantai secara berkelompok-kelompok. Penentuan jenis mangrove yang sesuai untuk ditanam, dilakukan dengan membandingkan kondisi lingkungan di lokasi penelitian dan kriteria menurut Kusmana $d k k$., 2003. Kriteria tersebut meliputi kelas penggenangan, frekuensi penggenangan pertahun sedangkan zonasi, pola pasang surut, salinitas dan tipe tanah.

Di stasiun I, II dan III diperoleh kelas penggenangan all high tides, frekuensi penggenangan 558 kali pertahun sedangkan zonasi pinggir pantai, pola pasang surut harian, salinitas 25-35 ppt serta tipe substrat lempung berdebu (stasiun I) dan lempung berpasir (stasiun II dan III). Berdasarkan kondisi tersebut maka jenis-jenis pohon mangrove yang direkomendasikan untuk stasiun I adalah 
Avicennia alba, A. officinalis, Rhizophora mucronata, Aegiceras corniculatum, A. floridum, Bruguiera gymnorrhiza, B. sexangula, Ceriops tagal, C. decandra, Excoecaria agallocha, Lumnitzera racemosa, Xylocarpus granatum. Sedangkan stasiun II dan III adalah pohon mangrove jenis $A$. marina, Sonneratia alba, S. caseolaris, $R$. stylosa dan R. Apiculata.

Dalam penentuan waktu untuk memulai melakukan penanaman mangrove sebaiknya harus mempertimbangkan kondisi oseanografisnya dengan tujuan menghindari ombak dan arus yang besar serta banjir dan musim berbuah (kematangan propagul).

Berdasarkan informasi yang diperoleh dari masyarakat setempat bahwa dalam waktu 1 tahun angin yang kencang terjadi sebanyak 3 kali yaitu pada musim angin barat, angin selatan dan angin timur, diantara ke 3 angin musim tersebut angin timur merupakan angin yang paling kencang, memicu terjadinya ombak dan arus yang besar yang terjadi pada bulan September memasuki puncak angin timur. Kondisi tersebut berpengaruh hanya pada stasiun II dan III. Sedangkan di stasiun I setiap 1 tahun sekali mengalami kenaikan volume massa air yang sangat tinggi sehingga perairan tersebut meluap hal ini disebabkan terjadinya hujan terus menerus dan adanya penambahan jumlah volume massa air yang mengalir dari muara Teluk Kendari dan terjadi pada bulan April.
Saat penanaman sebaiknya ditentukan juga dengan melihat jadwal pasang surut dimana penanaman dilakukan pada saat surut. Khusus untuk penanaman yang menggunakan propagul, waktu penanaman sangat tergantung pada ketersediaan propagul tersebut karena bahan tanaman berupa propagul bersifat cepat dewasa dan hanya bisa disimpan paling lama 12 hari. Oleh karena itu, pelaksanaan penanaman dengan propagul tersebut harus dilakukan selama musim berbuah masak.

Musim berbuah jenis-jenis pohon mangrove juga merupakan saat yang tepat untuk kegiatan pengumpulan bahan tanaman (benih) untuk memulai kegiatan produksi anakan di persemaian. Penanaman memakai anakan (bibit dalam polybag) harus dilakukan pada saat air surut sebab, kalau dilakukan dalam keadaan air pasang, media dalam polybag yang menyelimuti akar, dikhawatirkan rusak.

Penanaman mangrove bertujuan antara lain rehabilitasi lahan untuk mengembalikan fungsi ekologis dari lahan mangrove yang rusak atau meremajakan kembali hutan mangrove yang telah dieksploitasi. Teknik penanaman yang bisa diterapkan di pesisir pantai pulau Bungkutoko adalah penanaman dengan menggunakan bahan tanaman propagul dan penanaman menggunakan anakan (bibit dalam polybag).

Berdasarkan hasil tinjauan beberapa parameter yang diteliti, untuk di setiap stasiunnya penanaman mangrove dilakukan 
dengan menanam langsung propagulnya dengan menggunakan bahan tanaman berupa propagul dari family Rhizophoraceae sedangkan penanaman melalui anakan (bibit dalam polybag) menggunakan bahan tanaman berupa propagul dari family Sonneratiaceae.

Namun menurut Kusmana dkk., (2003) dari masing-masing teknik penanaman tersebut memiliki beberapa keuntungan dan kerugian antara lain sebagai berikut:

1) Penanaman dengan menggunakan bahan tanam propagul

Keuntungan:

- Merupakan cara yang paling mudah dan murah.

- Sifat buah yang vivipar (berkecambah di pohon) tidak memerlukan proses penyemaian.

- Propagul yang ditanam mempunyai kemampuan menghasilkan tunas tambahan apabila hipokotil bagian atas rusak dan pembentukan akar cukup cepat (kurang dari satu minggu).

- Di habitat yang cocok, keberhasilannya lebih dari $90 \%$ dan tegakan biasanya tumbuh baik dan seragam.

- Penanganan lebih mudah karena propagul lebih ringan dan sederhana bentuknya.

- Biaya penanaman relatif murah karena tidak perlu biaya persemaian dan penanaman dapat dilakukan dengan waktu relatif singkat.

Kerugian:
- Kegiatan penanaman hanya terbatas waktunya pada berbuah masak, karena buah (propagul) ini tidak bisa disimpan lama.

- Setelah ditanam, propagul relatif lebih mudah diganggu oleh kepiting dan teritip.

2) Penanaman dengan menggunakan anakan (bibit dalam polybag)

Keuntungan:

- Cukup fleksibel dari segi jadwal penanaman (tidak tergantung dari musim kemasakan buah).

- Kadangkala penggunaan bibit dalam polybag, lebih besar peluang keberhasilannya dan lebih cepat tumbuhnya disbanding penanaman propagul langsung.

- Cukup tahan terhadap gangguan hama.

Kerugian:

- Penanganan lebih sulit karena bahan tanaman yang lebih berat dan kompleks.

- Biaya penanaman relatif mahal karena perlu biaya persemaian.

- Akar bibit dalam polybag ini mudah rusak kalau pekerja ceroboh ketika mengangkut dan menanam. Karena itu, teknik ini membutuhkan pengawasan yang lebih ketat.

\section{KESIMPULAN}

Berdasarkan hasil penelitian dan pembahasan yang telah diuraikan, maka penelitian ini disimpulkan sebagai berikut:

1. Kondisi parameter fisika-kimia perairan pantai Bungkutoko di stasiun I, II dan III sesuai untuk dilakukan kegiatan rehabilitasi 
mangrove, yaitu mempunyai kemiringan alas yang datar dan landai, ukuran partikel substrat kecil, daya ikat partikel substrat sedang sampai lepas, keterkungkungan garis pantai terlindung dan semi terlindung serta terbuka, gelombang relatif kecil, simpangan muka air laut sedang, tipe pasang surut campuran condong ke harian ganda, kecepatan arus yang lemah, sedimen suspensi yang normal dan salinitas 25-35 ppt.

2. Jenis mangrove yang layak tumbuh dan berkembang di stasiun I adalah Avicennia alba, A. officinalis, Rhizophora mucronata, Aegiceras corniculatum, A. floridum, Bruguiera gymnorrhiza, B. sexangula,

\section{DAFTAR PUSTAKA}

Amal. 2000. Studi Kelayakan Areal Pemulihan Hutan Mangrove di Pantai Kecamatan Duampanua dan Cempa Kabupaten Pinrang Sulawesi Selatan. Tesis, Program Pascasarjana (S2), Universitas Hasanuddin. Makassar.

Baharuddin, N. 1994. Laporan Hasil Penelitian Model Pengelolaan Hutan Bakau di Pantai Sinjai Timur. Pusat Studi Lingkungan (PSL) Universitas Hasanuddin. Ujungpandang.

Darsidi, A. 1987. Perkembangan Pemanfaatan Hutan Mangrove di Indonesia. Dalam: I. Soerianegara, dkk (eds). Prosiding Seminar III Ekosistem Mangrove. MABLIPI : 27-37.

Dedi, S. 2009. Ekosistem Mangrove. http://web.ipb.ac.id/-dedi_s/index.php optioncomcontent\&task=view\&id=13\&it emid $=58$. Diakses tanggal 27 Maret 2009.
Ceriops tagal, C. decandra, Excoecaria agallocha, Lumnitzera racemosa, Xylocarpus granatum. Sedangkan stasiun II dan III adalah pohon mangrove jenis $A$. marina, Sonneratia alba, S. caseolaris, $R$. stylosa dan R. Apiculata.

3. Waktu yang tepat untuk mulai melakukan penanaman adalah musim berbuah propagul dan hindari musim angin timur pada bulan September dan musim angin barat pada bulan April.

4. Teknik rehabilitasi (penanaman) yang dapat diterapkan adalah penanaman secara langsung menggunakan propagul dan penanaman menggunakan anakan (bibit dalam polybag).

Hardjowigeno, S. 1992. Ilmu Tanah. Unit Pelaksana Teknis (UPT) Laboratorium Dasar Universitas Indonesia. Jakarta.

Kusmana, C., S. Wilarso., I. Hilwan., P. Pamoengkas., C. Wibowo., T. Tiryana., A. Triswanto., Yunasfi., dan Hamzah. 2003. Teknik Rehabilitasi Mangrove. Fakultas Kehutanan Institut Pertanian Bogor (IPB). Bogor.

Mantodiwirjo, S. 1994. Kebijaksanaan Pengelolaan dan Rehabilitasi Hutan Mangrove dalam Pelita VI. Bahan Diskusi Panel Hutan Mangrove. Mangrove Center, Denpasar, 26-28 Oktober 1994.

Nybakken, J. W. 1992. Biologi Laut Suatu Pendekatan Biologis. PT Gramedia. Jakarta. 
Ona., S.T., 2004. Studi Parameter Fisika Kimia Perairan untuk Budidaya Laut di Pulau Renda Kabupaten Muna. Skripsi Jurusan Perikanan Fakultas Pertanian Universitas Halu Oleo. Kendari.

Pariwono, J.I., 1989. Kondisi Pasang Surut di Indonesia. Pusat Penelitian dan Pengembangan Oseanologi-LIPI. Jakarta.
Taringan., M.S., dan Edward. 2003. Kandungan Total Zat Padat Tersuspensi (Total Suspended Solid) Di Perairan Raha, Sulawesi Tenggara. Pusat Oseanografi LIPI. Jakarta. 